\title{
Failures of Corporate Governance in Housing Cooperatives - Case Study
}

Waldemar Walczak'

Primary submission: 12.08.12 | Final acceptance: 28.12.12

\begin{abstract}
Purpose: The purpose of this paper is a discussion and in-depth analysis of the legal and organizational circumstances associated with the activities of Supervisory Boards in housing cooperatives.

Methodology: A critical analysis of the existing legislation, own analytical analysis of the source documents, supplemented by conclusions and observations formulated on the basis of a case study, for the preparation of which information has been used obtained from primary sources in the form of documents of the analyzed housing cooperative and information obtained through participant observation.

Findings: What has a decisive impact on the mechanisms of corporate governance in housing cooperatives are the direct behaviors of Supervisory Board members, as well as the lack of awareness and involvement of the residents, who do not want to actively participate in the life of the cooperative. A diagnosis is presented of the most important factors that influence the actual operations of the analyzed Supervisory Board. While the current legal regulations make it possible to ensure effective and proper control as well as adequate supervision over the activities of cooperatives.

Originality: The paper enriches the theory of management sciences in terms of a wider perception of the term corporate governance in relation to other organizations than companies. The presented methodological approach that is the basis for a comprehensive and thorough inspection of the activities of the Management Board can be used in other cooperatives as well. In the literature on the subject no similar analysis, supported by the results of own analytical research, had been found.
\end{abstract}

Keywords: corporate governance, supervisory boards, housing cooperatives, law regulations

$$
\text { JEL: M1, M10, K2, K29 }
$$

\footnotetext{
1 University of Lodz

Correspondence address: University of Lodz, Narutowicza St. 65, 90-131 Lodz, e-mail: waldek.lodz@wp.pl.
} 


\section{| Introduction}

Issues associated with corporate governance in the literature on the subject are usually narrowed down to the functioning of companies, which does not seem to be quite right, considering the fact that its essence should be to ensure an effective and substantial control of the activities of Management Boards while seeking to ensure an efficient system of organizational management in accordance with the applicable laws (Aluchna, 2007; Dobija and Koładkiewicz 2011; Jeżak, 2010; Jerzemowska, 2002; Peszko, 2006; Rudolf, 2008). Therefore, the mechanisms of properly understood governance in housing cooperatives should primarily focus on ensuring that the rights and interests of all residents are respected, because they are the key stakeholders who by paying their monthly rent finance the operations of the given organization.

Housing cooperatives are organizations that manage the common property of their members, and the main task of the Supervisory Board is to control the current activities of the cooperative and the Management Board, especially in terms of spending the money of the tenants and the management of common property. The functioning of housing cooperatives is based on the principle of community of property and organization, and the residents form their own local communities. Observation of the attitudes and behaviors of tenants, however, leads to the conclusion that in most cases people do not have sufficient knowledge in the field of the legal and organizational conditions that regulate the functioning of housing cooperatives, which also leads to a low level of involvement and the lack of real interest in issues of common concern. It is easy for people to complain about the constant increases in rent, mismanagement, neglected buildings, lawns, communal squares, but few take real action to change the chairman of the Management Board, who is entrusted with the management of the common, often huge, property. Few people are aware of the fact that it is the tenants that decide on the composition of the Supervisory Board, which appoints and dismisses the Management Board of the cooperative.

The purpose of this paper is to identify the main sources of weakness of the activities of the Supervisory Board in the studied housing cooperative, as well as demonstrating the impact that various factors have on real organizational processes. The Author does not limit himself to just theoretical considerations, but he also confronts them with own empirical experience gained through being a Supervisory Board member of a housing cooperative, which significantly enhances the substantive value of this paper.

The comprehensive research questions are to help answer the following questions:

- How do the legal and organizational conditions affect the selection procedure of Supervisory Board members?

- What causes the same people to run as candidates for Supervisory Board members year after year and what are their main motives?

- What areas and processes should be particularly taken into consideration by the Supervisory Board within the framework of their supervisory and control activities? 
- What factors have the greatest influence on the attitudes and behaviors of the Board members?

The in this paper adopted hypothesis is that in the analyzed housing cooperative the majority of the candidates and elected Supervisory Board members primarily focus in their activities on supporting the already created configuration and system of business relationships.

It is worth noting that on account of access to information and on the basis of the conducted comprehensive analytical research studies based on source documents it can be concluded that the findings and conclusions drawn are reliable, highly objective and cannot be called into question. This is particularly important in terms of the intended purpose of the research, because in his peregrinations the Author has adopted three fundamental methodological assumptions as the dominant feature and binder of the conducted study, which should apply in management sciences:

- the desire to know the truth about the studied phenomena, processes, organizational problems - a thorough identification, diagnosis and explanation of the real causes (sources) of their occurrence;

- the desire to generate knowledge, which will be used to develop effective methods and tools that will enable solving the diagnosed causes of the problems identified in the management practice;

- the desire to understand the relationships that exist between the studied phenomena, processes, problems, and other factors that affect the functioning of other entities - particular attention should be paid to the coincidence of processes, personal relationships and capital flows (Walczak, 2011b, p. 94)

The knowledge that creates the possibility to correctly diagnose and understand the sources as well as mechanisms of real phenomena and organizational processes, can be gained primarily through own experiences resulting from participation in a given organization. Previously acquired theoretical knowledge as well as analytical thinking skills are very helpful in research processes - they allow to identify and look out for the really important elements - however, only the possibility of actual verification in practice of specific events and organizational processes entitles to express real, rational, and deeply thought-out value judgments. Additionally it seems that the adopted integrative approach, consisting in combining knowledge in the field of management with the basics of law, is of essential significance for a reliable analysis of the outlined problem.

The set out conclusions and findings do not give grounds for generalizations, i.e. for assuming that the diagnosed failures can also be confirmed in other cooperatives. However, it can be assumed that a comprehensive and thorough audit conducted in accordance with the proposed methodology and within the framework of the outlined functional areas would lead to identifying comparable negative phenomena in other cases. 


\section{Research Method}

A case study is a research method that is considered to be a detailed description of a real object, phenomena or processes, conducted in order to explain the causes, results and determinants of the occurrence of given events or the functioning of an organization under certain conditions. It is an idiographic approach, of which the main objective is to thoroughly analyze, present and explain the causes of the studied processes and events. It fits in with the interpretive methodology and the inductive nature of management sciences. According to S. Lachiewicz and M. Matejun, using the case study method is associated with the following restrictions: low representativeness of the results, intuitiveness and subjective judgments, high time-consuming and high costs of research (Matejun, 2011, p. 203-206). Quite different is the case when the researcher has full and unrestricted access to source documents, and also has the possibility to empirically analyze the studied organization. These are the main circumstances that guarantee that a research process using this method can provide a more accurate and in-depth image of the studied reality, and particularly allows for an accurate interpretation of the sources and circumstances of specific phenomena, but only on the condition that we have a chance to personally participate in the operations of the analyzed organization.

Only then are the expressed opinions and value judgments objective and true - they cannot be called into question because they are based on specific documents, facts and events, and not on feelings or opinions voiced by others, such as in the case of a survey questionnaire, for example. Moreover, the knowledge gained from own empirical experience is reliable and well-grounded, because it is not derived from indirect participant observation, but is the result of an accurate analysis of the everyday organizational realities. It is esoteric knowledge, which cannot be acquired if there is no possibility to personally participate in certain events (Walczak, 2011a; 2011b).

Participant observation is, simply speaking, a research method that occurs when the researcher becomes a participant in a given community or organization, and conducts certain research studies based on his own observations. In other words, the researcher puts himself in a close and direct relationship with those observed, and participation in real organizational processes is the source of research material (Konecki, 2000, p. 145). Such qualitative research studies (qualitative methods) are most often used in cases when the researcher wants to acquire in-depth and comprehensive knowledge on a given subject, and places particular emphasis on an accurate diagnosis of the essence of the given phenomenon and on identifying the sources of the occurring organizational problems. It is worth noting that an insider researcher has greater possibilities of obtaining information, he knows the meaning of the activities of the people in the given organization, he can learn through experience, which is undoubtedly the most important advantage of participant observation (Kostera, 2008). On account of his participation in the given environment, the researcher has the opportunity to learn more about real organizational phenomena and processes, and it is also easier for him to 
conduct a careful analysis of the given problem taking into account the specific circumstances, as well as to see certain events in the right context, i.e. to notice the coincidence of certain processes, and to understand the causal relationships between them. It can therefore be assumed that participant observation as a method of qualitative research provides an opportunity for a very detailed description of the given issue, and it also creates the possibility for an indepth explanation and accurate interpretation of specific events, which makes such qualitative research attractive for many inquisitive scientists (Silverman, 2010, p. 38). However, it needs to be added that it rarely happens that researchers have the opportunity to use this research method, simply because it hardly ever happens that they are allowed to become a member of the organization. Moreover, this research method requires that the researcher previously acquires thorough knowledge of the problem area as well as professional experience, which would allow him to properly direct his thought and cognitive processes to accurately selected issues. Analytical thinking skills and a holistic approach to organizational processes such as personal relations and financial flows play a crucial role. It is also important to keep one's distance and to maintain an impartial approach in the process of analysis and interpretation of the given issues, in order to avoid being accused of a lack of objectivity.

Direct involvement will obviously entail some emotions, which always come up, which could result in a lack of objectivity, which is why the Author in his deliberations limits himself only to specific events, which have been recorded in documents and are indisputable.

The above statement, i.e. that in-depth knowledge and understanding of real organizational processes is only possible when the researcher becomes member of the given institution, should not raise any doubts. In any other case, our knowledge is at best an illusory notion of the principles and mechanisms of its functioning. In the vast majority of cases, researchers obtain their knowledge mainly through surveys or direct interviews with selected members of the organization, mostly management representatives. Unfortunately, such knowledge is difficult to verify objectively, because the opinions and value judgments that are expressed by the respondents do not necessarily have to be true, and in addition it is not possible to confirm their reliability, because no one can guarantee the researcher unlimited access to all source documents. That is why the Author has decided to seize the opportunity and he conducted his research based on concrete documents, which he has access to because of his position on the Supervisory Board of the analyzed housing cooperative. The experience gained because of this has enabled a comprehensive look at the overall management processes in the analyzed cooperative, and the in previous studies developed analytical thinking skills and systematic approach to organizational problems made it possible to identify the relevant functional areas that require detailed analysis and peregrination.

The conducted research focuses primarily on real events and irrefutable facts that have been documented, in order to avoid any suspicion of a lack of impartiality or lack of maintaining an appropriate distance with respect to the presented results. 


\section{| Housing Cooperatives - The Common Property of All Members}

We should start with the legal basis in the field of housing cooperatives in Poland. The basic laws that govern the operations of housing cooperatives in Poland are: The Act of 16 September 1982 Cooperative Law (Journal of Laws of 1982 No. 30, item 210, as amended) and the Act of 15 December 2000 on Housing Cooperatives (Journal of Laws of 2001, No. 4, item 27, as amended).

A housing cooperative is a legal entity of the corporate type (association, union), but has a different legal status than an association or foundation, because the principles on which its operations are based are laid down in a separate law. Arguments in favor of a separate positioning of cooperatives in Polish legislation are most fair and reasonable, given the important social purpose and the subject of their activity, which is to meet housing needs and maintain the administered buildings in a condition that enables their proper use.

There is no doubt that at the beginning of their existence housing cooperatives were voluntary associations, which made it possible for poor people, who could not afford to own their own home, to build and maintain flats based on collective efforts. However, it can be assumed that despite the dynamic development of single-family housing, cooperatives will remain to be an important element of urban reality for many years to come, making it possible for many millions of less wealthy Poles to acquire their own dwelling. Looking at the increasing number of single-family houses built in the vicinity of large cities, it can give the wrong impression that in Poland everybody can afford such a luxury. Unfortunately, the reality is that for many Poles (especially young ones) owning an apartment in a flat building still remains the subject of their dreams and desires.

Housing cooperatives as independent business entities co-create the social market economy system. It should be clearly emphasized that the property of a housing cooperative is private property - it is the common property of all members.

Pursuant to Article 1 item 1 of the Act on Housing Cooperatives, the aim of a housing cooperative is to fulfill the housing and other needs of its members and their families. This includes not only supplying apartments and single-family houses, but also premises for other purposes. A housing cooperative is not allowed to make profit at the expense of its members, especially not by virtue of transformation of rights to the premises.

Based on this provision, the aim of the cooperation of citizens within housing cooperatives is not to make profit, but to operate for the common good of all residents.

The purpose of the business activity of cooperatives is to meet the needs of its members, and they should strive to ensure the highest quality of services. The key priority of the activity of housing cooperatives should be considered the rationalization and optimization of the maintenance costs of the technical infrastructure, while striving to make use of the available resources - land, 
commercial premises, etc. Housing cooperatives operate according to the non-profit principle, which means that they cannot make profit at the expense of their members. However, this does not mean that they should not strive to achieve good economic results through their operations. It can even be said that it is the principles of rational management of the owned property that should be the dominant feature and binder of the activities undertaken by the Management Board. Harmonizing and balancing all the different needs and expectations of the local community is the most important challenge that should inspire those responsible for the management as well as those who perform functions of control and supervision, i.e. the Supervisory Board members (Walczak, 2011a, p. 45-46).

Housing cooperatives are member organizations, bringing together groups of people living in a given area that share certain economic and social relations. The economic relations are associated with participation in the operating costs of multi-family residential buildings, the maintenance of common recreational areas, playgrounds, parks, streets, parking lots, etc. While the social relations are identified with belonging to a local community, which should ensure attractive living conditions in the residential complex. However, it is regrettable that members of housing cooperatives show little activity and low involvement in local problems, and all they do is complain about the high rental rates, the frequent increases in payments, polluted lawns or dirty stairwells. The truth is that they are largely responsible for this state of affairs, and their passive attitude is somewhat like an expression of acceptance for the ineffective actions of the Management Board of the given housing cooperative. It needs to be remembered that it is the residents that elect among themselves representatives to the Supervisory Board, which decides on the appointment and removal of Management Board members. In this context, it is worth noting that the functioning of housing cooperatives is characterized by self-rule, autonomy in decision making and at the same time a lack of direct control or supervision by an appropriate public authority.

Given the fact that, as mentioned earlier, pursuant to Article 3 of the Act Cooperative Law: the property of the cooperative shall be the private property of its members, properly understood corporate governance is supposed to protect the interests of the residents. Andrzej K. Koźmiński has expressed an extremely valuable insight, saying that particular attention should be given to ensuring that some groups involved in the functioning of the organization do not make undue profit at the expense of other groups, and that their resources are used effectively for the benefit of all (Koźmiński, 2005, p. 48). This statement aptly captures the essence and the primary objective that the members of the Supervisory Board should strive for, which is the fundamental institution performing the function of corporate governance in housing cooperatives.

\section{Rules for the Selection of Supervisory Board Members in Housing Cooperatives}

In accordance with Article 35 §1 of the Act of 16 September 1982 Cooperative Law, the bodies (authorities) of housing cooperatives are: 
- The General Meeting, which is the supreme body of the cooperative;

- The Management Board - the executive body - persons authorized to represent the cooperative to the outside world, that have decision-making powers in the field of managing the entrusted property and are authorized to perform legal transactions leading to financial implications;

- The Supervisory Board - exercises supervision and control over the operations of the cooperative, and particularly controls the actions and decisions of the Management Board;

- In cooperatives that have Representatives Meetings instead of General Meetings - Member Group Meetings (Article 59).

It is worth noting that every member of a housing cooperative is entitled to participate in the General Meeting. Moreover, everyone has the same rights, as everyone is entitled to one vote. Based on this statement, it is clear that the number of votes at a General Meeting does not depend on the number of shares held as in the case of companies, which significantly sets housing cooperatives apart from these kinds of enterprises. A member may participate in the General Meeting in person only, unless otherwise provided by law (Article $36 \S 2$ of the Act Cooperative Law).

Given the marked out objective of this paper, it is reasonable to thoroughly discuss the conditions associated with the selection of members of Supervisory Boards in housing cooperatives, and then to analyze the adopted attitudes and organizational behaviors based on a specific example taken from practice.

First of all, it should be mentioned that the Supervisory Board should focus in its operations on the performance of its statutory duties, such as control and supervision over all operations of the cooperative, and especially over the accounting for the actions of the Management Board, with particular emphasis on the legality and economy of the undertaken activities in the field of financial management and the management of the assets of the cooperative, which are the common property of all its members - ensuring that the money of the tenants is spent sensibly, observance of the rights of the cooperative members. In order to effectively fulfill all the assigned duties, besides willingness, time and commitment, without a doubt also appropriate substantive qualifications are needed, such as extensive knowledge in the field of law, economics and finance. Pursuant to the Act of 16 September 1982 Cooperative Law, Only members of the housing cooperative may be elected to the Supervisory Board (Article 45 §2). It should be added that these elections are conducted by secret ballot from among an unlimited number of candidates (Article 35 §2). Significant legal restrictions result from the provisions of Article $8^{2}$ item 2 of the Act of 15 December 2000 on Housing Cooperatives - The Supervisory Board of a housing cooperative may not include persons who are employees of the cooperative. Any resolution on the election of such person to the Supervisory Board is invalid. As soon as a Supervisory Board member is employed, his/her membership in the Supervisory Board of the same cooperative shall be terminated.

Based on the above provisions of law it should be noted that the legislature has not provided for any qualification requirements that the Board members should hold, which means that 
each member of the cooperative has equal rights and a real chance to apply for this function, regardless of whether his knowledge and education will guarantee a proper performance of the assigned duties. Such an approach is undoubtedly a reflection of the equal rights of all members of a housing cooperative. However, when considering this issue in terms of management sciences, it should be pointed out that the lack of qualification requirements with respect to the Board members, such as having a higher education, knowledge in the field of cooperative law, knowledge of the Act on Housing Cooperatives, knowledge in the field of organizational, legal and economic issues associated with the activities of housing cooperatives, causes a substantive discussion to be rather pointless and all that matters is the outcome of the vote. Unfortunately, this is a key feature of decision-making by collective bodies, where it often happens that the power of the number of votes overcomes the power of knowledge and substantive arguments. Not always is the person who wants to introduce solutions that are beneficial to all the residents right, but the group of people that has the majority of votes in the Supervisory Board will always be successful. This fact is mostly responsible for the overall activities of Supervisory Boards and the undertaken actions (Walczak, 2011a, p. 47).

The prohibition on employment in a housing cooperative in conjunction with being a Supervisory Board member does not raise any doubts, because such legal regulations guarantee that real conflict of interest can be avoided. However, it seems that in reality there are many more situations that give reasonable grounds for suspecting partiality or self-interest of the Board members, which unfortunately have not been identified by the legislature, such as business activities using common property - in commercial premises of the cooperative. In this context, it should be pointed out that the absence of a statutory prohibition on being member of a control and supervisory body, such as the Supervisory Board of a housing cooperative, while making considerable profit from running a private business using the common property of the residents of the cooperative, seems to be a misunderstanding, because such situations constitute an irrefutable argument in favor of a real conflict of interest and create the opportunity to make decisions that lead to the financial benefits of a small group of beneficiaries. A good example is the fact that it is the Supervisory Board members that, among other things, adopt resolutions on the distribution of commercial premises without a tender, for the purpose of running a business there by a particular person or company, while also establishing the lease terms and rental rates.

Another important circumstance is given in Article $56 \S 3$ : Members of Supervisory and Management Boards must not engage in businesses that are in competition with the cooperative, and in particular they must not participate as partners or directors in enterprises operating in competition with the cooperative. Violation of the prohibition of competition forms a basis for the removal of Board members and causes other legal consequences provided for in separate legislation. Unfortunately the legislature has not clarified how this should be interpreted.

In light of the cited provision of the law a legitimate question arises: how should entrepreneurs whose business is in competition with the cooperative be defined? Does such a prohibition apply 
only to Board members of other cooperatives, or does it also apply to persons holding rank-andfile positions in another cooperative? Does working for a private property developer count as being involved in a competitive business? If the people working for cooperatives (employees) are involved in cleaning the area, taking care of the greenery, the execution of simple renovation works, plumbing repairs, painting, etc., can, for example, running a business in this field, or being member of the governing bodies of a company performing similar work, be treated as operating in competition with the cooperative? Such reasonable doubt may arise if, for example, a company that is managed by a member of the Supervisory Board or Management Board obtains (receives) a lucrative contract to perform the above-mentioned work for the cooperative.

In an attempt to answer these questions, operating in competition with housing cooperatives should be defined in terms of a situation in which separate business entities seeking to achieve their targets within the framework of their business activities create the opportunity for potential customers to meet their housing needs by choosing the offer that stands out among the others based on its price, attractiveness, location, quality standards, and other features that are supposed to convince the customers to enter into contracts and transactions with them, and not with other business entities.

Thus, it is not the territorial area of the business activity that determines the competitiveness, nor the legal and organizational form, but above all the scope and nature of the business. Therefore, it can be assumed that operating in competition with housing cooperatives involves trading real estate, being member of the governing bodies of companies involved in the sale of land for construction projects, real estate leasing, real estate management, as well as being a Board member of another housing cooperative, company of a social building society, developer or housing community. In addition, members of the Supervisory Board and the Management Board should not be involved in businesses that may give reasonable grounds for suspecting partiality or selfinterest, which no doubt could include business activities conducted for the cooperative, or performing other jobs (services, selling goods) on the basis of civil law contracts.

Continuing these considerations, it needs to be pointed out that Article 57 of the Cooperative Law contains the following provision: the Supervisory Board may not include persons who are the managers of current businesses of the Cooperative or representatives of the Management Board, or persons who are married to, in a relationship of consanguinity or affinity in the straight line or in the collateral line to the second degree with members of the Management Board or the managers of current businesses of the Cooperative, which indicates that the prohibition on combining functions literally has been defined only in relation to other cooperatives.

Obviously, Supervisory Board members also cannot simultaneously be members of the Management Board, however, the legislature does provide for the possibility of delegating one or more Supervisory Board members to temporarily perform the function of member(s) of the Management Board. In this particular case, there is no need to give up the mandate, but membership in 
the Supervisory Board shall be suspended for the duration of the function, and after the election of a new composition of the Management Board the delegated person(s) returns to their previous position on the Supervisory Board. Such a solution is mainly supposed to enable a quick composition of the Management Board as a result of personnel changes. It should be noted that this solution is a good and reasonable one, as it makes it possible to rapidly make all the necessary decisions.

In housing cooperatives the Supervisory Board is elected by the General Meeting, which is the supreme body (highest authority) of the cooperative (Article 36), while in cooperatives where the General Meeting is substituted by the Representatives Meeting - the Member Group Meeting elects the Supervisory Board members (Article 59 \$1, §2, Cooperative Law). What should be considered as important in this matter is the fact that in elections by member groups we are dealing with a smaller number of people entitled to vote.

So in practice it may turn out that with a low turnout just a few votes from immediate family and next-door neighbors are enough to become member of the Supervisory Board. However, some argue that this solution makes it possible to form a Supervisory Board that is a proportional and full representation of the people living in the respective enclaves of the blocks of flats.

However, the biggest misconception is the fact that it is possible to run for and be elected to the Supervisory Board and at the same time be member of the Member Representatives Meeting (ZPCz). My own experience and observations entitle me to state that such a situation is notoriously exploited, which causes the same people to play a dual role. This is a complete confusion of concepts and a clear - undeniable conflict of interests, because it is the Member Representatives Meeting that accepts and endorses the activity report of the Supervisory Board. The oddity of this situation is undeniable, and additionally it happens under the majesty of the law. In Poland there still is a certain group of housing cooperatives that have not adapted their Articles of Association to the amended on 14 June 2007 Act on Housing Cooperatives, and the General Meeting is replaced by the Member Representatives Meeting.

While analyzing the introduced changes it is essential to point out that in accordance with the legal provisions of Article $8^{2}$ items 3 and 4 It is not permitted to be a member of the Supervisory Board for longer than 2 consecutive terms of office of the Supervisory Board, and the term of office of the Supervisory Board may not last longer than 3 years. These statutory limitations regarding consecutive terms of office of Supervisory Board members are particularly important in terms of the present analysis. An important and decisive factor in this matter is the standpoint of the Constitutional Tribunal, which found that while the contested provisions did interfere in the freedom of association in terms of the passive right to vote in processes of electing housing cooperative authorities, this interference is justified in light of Article 31 item 3 in conjunction with Article 76 of the Constitution. It was pointed out that this theory is supported by the views set out in the judgment in case $\mathrm{K} 42 / 02$, in which the Constitutional 
Tribunal concluded the following: Article 76 of the Constitution, according to which public authorities shall protect «consumers, customers, hirers or lessees» against, among other things, "dishonest market practices», also applies to members of housing cooperatives (see more on the subject: Walczak, 2011a, p. 51-54).

These new regulations deserve a very positive opinion, because in many housing cooperatives the same people are Supervisory Board members for many years, which is conducive to creating strong dependencies and the formation of particularistic interest groups, like in the parliament, where some members have not changed for over 20 years.

Finally, something should be said about the remuneration of Supervisory Board members of housing cooperatives. Pursuant to Article $8^{2}$ item 1 of the Act on Housing Cooperatives: Members of other than the Management Board bodies of a housing cooperative perform their functions voluntarily, but the Articles of Association may provide for remuneration for their participation in meetings, which shall be paid in a monthly lump sum regardless of the number of meetings and must not be greater than the minimum wage referred to in the Act of 10 October 2002 on Minimum Wage.

It should be noted here that the legislature has not set any restriction on the maximum remuneration that Management Board members of a housing cooperative may receive, but only introduces restrictions in relation to Supervisory Board members. This is undoubtedly a bizarre situation that could give rise to reasonable doubts, because we are clearly dealing with the discrimination of one group here. What's more, such a solution significantly differentiates the mechanisms and principles of the remuneration of Supervisory Board members in housing cooperatives from those applied in commercial companies, which, similarly to cooperatives, often manage huge assets that are privately owned. In order to fairly and honestly perform their functions, Supervisory Board members in housing cooperatives must have a very extensive and current legal knowledge, a good knowledge in the field of economics and finance, and above all they must show commitment - which involves many hours of dedication to substantive work. If to that you add the fact that housing cooperatives play an important social role because of their objectives and tasks, it seems even more incomprehensible that statutory restrictions are introduced regarding the possibilities of remunerating Supervisory Board members, which in turn leads to lower standards of supervision and control - certainly, this cannot be regarded as acting in the interest of the residents. That is why the statutory depreciation of the rank and importance of the work of Supervisory Board members in housing cooperatives, by setting such low remuneration levels, undoubtedly is an element that undermines the motivation to perform this function. The consequence of the outlined phenomena is the tendency that constantly the same people run as candidates for Supervisory Board members, who seek to achieve completely different benefits for themselves as a result of the performed functions than the lump sum remuneration. For them it is all about the power that they have, which is associated with the possibility of a real impact on the processes of capital flow and the management of common property. 


\section{The Attitudes and Behaviors of the Supervisory Board Members of a Housing Cooperative - Case Study}

The analyzed housing cooperative administers 190 buildings, in which there is a total of 5288 flats, and is considered to be one of the largest housing cooperatives in Lodz (Poland). It operates as an independent entity since 1995, as a result of a separation from a larger housing cooperative. The Supervisory Board consists of 15 members appointed by Member Group Meetings, because to this day the Articles of Association have deliberately not been adapted to the applicable law, i.e. the Act on Housing Cooperatives, so that the same people can be elected to the Supervisory Board over and over again. For a better illustration and clarification of the situation I could refer to the fact that in 2011 the formation of the new Supervisory Board included 12 people that had already performed this function many times before, especially two of them, who were re-elected for a third consecutive term. Thus, only three newly elected people started their function as Supervisory Board members for the first time. Such events are the result of the fact that these Member Group Meetings are attended by a very small number of residents. For example, in 2011 it was possible to elect a Supervisory Board member based on three votes (including his own vote for himself), because that was how many people entitled to vote showed up to the Meeting. On average, per member group, including approximately 1000 people entitled to vote, no more that 30-40 people took part in Meetings. This shows how little people are aware of the rights that they are entitled to. However, on the other hand, this passivity show to what extent the residents are discouraged to civic participation on account of the overall pathology occurring in the housing cooperative.

When analyzing the composition of the Supervisory Board it is worth mentioning that the earlier described group of 12 people was also elected to the Member Representatives Meeting (ZPCz), and this situation associated with the performance of a dual role by the "irreplaceable" members has functioned in the cooperative for many years - since its establishment. In the attempt to more closely illustrate the composition of the Supervisory Board it should be noted that among its members currently there are people who definitely should not be there: two of them are in litigation with the cooperative and have not paid their credit obligations for years, two members have many thousands of debt due to unpaid rent, some members are running a business in the commercial premises of the cooperative, and two members have been re-elected for a third consecutive term. The Supervisory Board includes five women (three of which are part of the Presidium) and 10 men. For the most part the Supervisory Board consists of people that collect disability or retirement benefits, including two retired police officers. Most of the Supervisory Board Members (75\%) do not have a higher education. In terms of education the men clearly dominate - only one woman has a university degree. While the women have much more time to work on the Board, as only one of them is professionally active. One of the men, a permanent member of the Board who has been running a business in one of the commercial premises of the cooperative for many years, has a vocational education. One of the men, who is Supervisory Board member for the first time, has a $\mathrm{PhD}$ in economics. 
Over the period from July 2011 to March 2012, one person, who was running a business in one of the commercial premises of the cooperative that was obtained without a tender and on highly concessional terms, resigned from the membership on the Board, and one person was effectively removed from the Board by the Member Group Meeting at a written request, in accordance with the Articles of Association supported by $1 / 10$ of the members of the given enclave, which had happened for the first time in the history of the residential complex. As a replacement for those people, new members of the cooperative were elected based on the highest number of votes (for more information see Walczak, 2011b, p. 94-106).

At the beginning of its term the Supervisory Board performed its functions of control and supervision very thoroughly and there was clearly a real desire to sort out the affairs of the cooperative and to break the system of particularistic dependencies and interests that had been functioning for years. This entailed enormous commitment and the sacrifice of a large amount of free time in order to conduct a thorough and in-depth financial control of the cooperative. During this time common shared beliefs and values could be observed within a certain group of people, especially among the new Supervisory Board members, who set themselves the objective to sort out the mess in the cooperative - such as wasting the money of tenants. In order to accurately identify and diagnose the actual situation of the cooperative, a number of assumptions for the audit activities were adopted, which may serve as well-developed methodological standards to be followed by other cooperatives as well, for Supervisory Board members that want to reliably perform their functions, i.e. to conduct an objective assessment of the overall activities of the cooperative in terms of the legality and economy of the undertaken activities associated with observing the rights of the tenants and managing their common property.

The first step was to obtain reliable information about the current issues related to the functioning of the cooperative, in order to be able to plan further action accordingly. In this process the employees turned out to be extremely helpful, who were willing to share their observations and insights. Most of them were also residents of the same residential complex. The result of this phase of preparatory activities was a request submitted to the Management Board to present reliable information and to give access to all documents, which would be the basis for an in-depth analysis that would include, among other things, the following issues:

The to the Supervisory Board submitted documents clearly confirmed the validity of the earlier observations and the analytical skills to accurately identify the key processes and issues that require thorough investigation. Basically, they completely exposed the entire system of capital connections and dependencies, which in many cases confirmed the previous assumptions that numerous irregularities and pathologies could be found within the cooperative. The submitted documents proved to be incriminating and shocking not only for the actual Management Board, but they also revealed just as many shortcomings and failures in the functioning of the previous Supervisory Board, most members of which are still in office in the current term. It should be added that many of the documents were discovered only by way of the great determination and commitment of several new Supervisory Board members, who devoted their free time to 
Table 1 | The scope of issues and matters subject to thorough audit by the Supervisory Board at the beginning of its term in 2011

\section{Documents and issues for thorough and in-depth audit by the Supervisory Board}

Subject area and scope: organizational structure, human resources, remunerations:

- duties and responsibilities of the respective Management Board members of the cooperative;

- organizational structure of the cooperative - (managerial and rank-and-file positions), scope of activity of the respective organizational units, the hierarchy of positions occupied by employees - qualification requirements, knowledge, education;

- precise and clear explanation of the principles and criteria of recruitment associated with hiring employees for different positions - substantive qualification requirements, remuneration policy (clarification of the largest remuneration gaps);

- additional civil law contracts concluded with employees in the years 2008-2011 - who were they concluded with, for what amounts, for what purpose, what is their scope and subject, including the scope of activities for the respective positions.

Subject area and scope: financial flows - invoices, contracts and ties with external companies:

- a compilation of information on all contracts with external entities, specifying: the subject and scope of the contract, the date of signing, the name and address of the company, a list of persons authorized to represent the company, the amount for which the contract is concluded, the duration of the contract, the drawn up annexes to contracts - a precise indication of the amendments that have been introduced in the respective §, mode of termination of the contract;

- a compilation of information on the decisions on all tender procedures in the years 2008-2011 (tender committees, tender committee protocols);

- a compilation of information on all contracts concluded with external entities in the years 2008-2011, excluding tender procedures, orders etc., with detailed information in accordance with the requirements outlined above.

Subject area and scope: commercial premises and debt:

- information on the form of allocation of premises (tender procedure and without a tender) and the applicable fees for commercial premises that have been established for all people running a business with the use of the property of the cooperative, and especially with respect to those persons that have performed and still perform functions in the Supervisory Board, the Member Representatives Meeting, stating the exact names, the type of business activity, the area and location of the business premises, the monthly fee per $\mathrm{m} 2$, along with a specification of the periods of office since the establishment of the cooperative;

- information on the amount of debt of tenants of commercial premises and the actions undertaken by the Management Board;

- information on the amount of debt of residents due to unpaid rent, undertaken measures in terms of debt recovery.

Subject area and scope: finances of the cooperative:

- analysis of how the financial and economic plan for 2011 is elaborated - detailed information on the first six months - highly legible and explicit clarification of the structure of the basic operating costs, particularly in the following positions: costs of legal services, bank fees, cleaning the area - companies, maintenance plumbing, impersonal wage fund, horticultural maintenance of common areas, etc.;

- implementation of the maintenance/renovations plan and a detailed analysis of how the Cable TV and Internet plan for the year 2011 is implemented - concrete information on the first six months - highly legible and explicit clarification of the structure of the basic operating costs, particularly in the following positions: the shared costs of Cable IV and Internet, bank fees, wage fund and surcharges, amortization and depreciation; the Internet - external connection costs, the shared costs of TV and Internet, network administration.

Subject area and scope: lawsuits - housing loans and mortgages:

- information on all pending legal proceedings;

- the costs incurred by the cooperative for lost lawsuits;

- changes in mortgage securities, correspondence with the court and banks;

- information on lawsuits brought by employees.

Subject area and scope: actions undertaken by the previous Supervisory Board:

- the resolutions adopted by the previous Supervisory Board;

- the minutes of the meetings of all Member Groups, the Member Representatives Meeting;

- the protocols of the audit committee of the previous Supervisory Board.

Source: own elaboration. 
conduct a comprehensive and thorough audit of the documents. Using their knowledge and skills, the new Supervisory Board members conducted an exceptionally accurate and substantial audit of the key problem areas associated with the functioning of the cooperative. The previous Presidium of the Supervisory Board had adopted a very good policy, according to which all identified issues requiring clarification should be carefully and precisely defined and included in the agenda, which is communicated through the local Cable TV to all residents of the residential complex. It was decided that the meeting of the Supervisory Board, during which all the described issues would be discussed, would be held in a space where all the invited residents could attend and listen to the discussion. As a result of such openness and transparency of the activities of the Supervisory Board, for the first time in the history of the cooperative everyone could find out the truth about the actual issues and problems associated with its current functioning. The meeting of the Supervisory Board was met with a favorable response of the residents, who participated in large numbers in the ongoing two-day session, which resulted in the removal of all the members of the previous Management Board and termination of their employment, followed by, at the request of a group of the Supervisory Board members, the removal of the chairman of the Supervisory Board, whose actions had lead to the disclosure of all the hitherto hidden facts.

Some of the most outrageous wrongdoings included orders placed with external companies, which, despite having signed permanent contracts, received additional orders for jobs that fell within the scope of the contracts and that amounted to nearly a million Polish zloty. These orders were based on annexes to the contracts, but the previous Supervisory Board was not informed about them (or rather, the Supervisory Board was not interested in them). Another example of such misconduct were purchases of goods and services bypassing the applicable internal regulations (without a tender the cooperative can make purchases of goods and services of a value not exceeding 5 thousand Euros), in which case, for example, invoices were discovered that amounted to several millions for the purchase of electronic equipment for inflated prices, not directly from the store (authorized distributor) but through an outside company run by two individuals who, without a tender, got a contract for the administration of the Cable TV network and the Internet. Furthermore, business premises were being allocated without a tender and on highly concessional terms to members of the Supervisory Board and Member Representatives Meeting, while the rental rates for premises in the same location and similar surfaces are even four times higher for other tenants. Other examples include the sale of rights to perpetual usufruct of real estate and land below its value based on an appraisal drawn up for one client who applied for the tender, or giving lucrative jobs without tenders at inflated prices always to the same companies. This is only a small fraction of the discovered pathologies that had been going on within the housing cooperative for years, but were carefully hidden from the residents, because only a small group of trusted people had access to the documents and knowledge of what was going on. It should be noted that the annual revenue of the cooperative amounts to more than 33 million Polish zloty, which means that there is a lot of money of the residents to spend. 
Furthermore, an interesting coincidence should be pointed out, namely that in the case of the employees that were responsible for the respective irregularities all of a sudden there was a deterioration of health, as a result of which they are currently still on sick leave. However, since then the attitude of the Supervisory Board Members has significantly changed, who felt that subsequent Board meetings should not be attended anymore by such a large number of invited residents, that there is no need to drill down into or further explain certain issues, to the extent that they forced the next Management Board to withdraw the termination of controversial and unfavorable for the cooperative contracts with outside companies, which clearly demonstrates the "credibility" of the Supervisory Board members, who reached this decision by a majority of votes. At the moment, the vast majority of the Supervisory Board members have come to an agreement that they will, for example, apply different standards in terms of debt recovery measures against the tenants with rental debts (exclusion from membership) and different ones against Supervisory Board members that are in the same situation, and now no one wants to go back to the previous issues anymore.

When analyzing the rental rates interesting relationships and dependencies can be observed. For example, low rental rates are usually observed for business premises that were rented without a tender. Another confirmed dependency that is characteristic of the group of these beneficiaries is that the tenant is usually a good friend of the Supervisory Board members, and on top of that was a Supervisory Board member for many years, or is part of the highest authority of the cooperative, which is the Member Representatives Meeting (ZPCz). This is the actual reality that reflects the rules for running a business in a housing cooperative - it is mainly different kinds of arrangements and knowing people that determines the success of the business. This is another topic that the Supervisory Board has not returned to in over six months, and attempts to put this item back on the agenda ended in failure.

Another noticeable change in the attitudes and behaviors of the Supervisory Board members is the fact that for most of them it was not a problem that rent increases were introduced that were not in accordance with the applicable law and no substantive arguments could affect the outcome of the vote. Similarly, decisions were reached to, for example, delegate a Supervisory Board member to the Management Board, who at the same time was a representative at the Member Representatives Meeting and had not submitted the necessary resignation from the other function within the set time limit. In the analyzed case we are dealing with an obvious and indisputable violation of the law - the Act Cooperative Law Article 56 § 1: It is prohibited to simultaneously be a member of the Management Board and a representative at the Member Representatives Meeting of the same housing cooperative, and according to Article $42 \S 2$ : Any resolution in conflict with the Act is null and void.

In light of these provisions of the law it is not allowed to delegate someone to be a temporary member of the Management Board, who at the same time is a representative at the Member Representatives Meeting. However, these arguments did not convince the Supervisory Board 
members, who adopted by a majority of votes a resolution to temporarily delegate a Supervisory Board member that simultaneously was a representative at the Member Representatives Meeting. This means that they adopted a resolution that is in conflict with the provisions of the Act Cooperative Law and the Articles of Association of the cooperative, which took place in the presence of legal advisors that provided legal assistance during the Supervisory Board meeting. The fact that the resolution violates the provisions of the Act is a relevant factor based on which it can be determined that the resolution is invalid under the law, and that all the actions undertaken by the person delegated to the Management Board will therefore not have any legitimacy and could expose the housing cooperative to serious consequences. Article $39 \S 1$ of the Polish Civil Code expressly provides that Anyone who, acting as a body of a legal person, concludes a contract in its name without being its body or exceeding the scope of authorization of that body, shall be obliged to return what s/he has received from the other party while performing the contract and to redress any damages which the other party has incurred as a result of the fact that it concluded the contract unaware of the lack of relevant authorization.

Another challenge that the Supervisory Board and the Management Board of the housing cooperative currently have to deal with is the matter of adjusting the Articles of Association to the applicable law, because towards the end of December 2011 the cooperative received a letter from the National Cooperative Council (KRS) with the information that the District Court for ŁódźŚródmieście, Commercial Court has filed a request to take action for the liquidation of the discussed cooperative on account of the persistent and flagrant violation of the provisions of the Act on Housing Cooperatives by not adjusting the Articles of Association to the current requirements of the Act, in particular to Article $8^{3}$.

Article $8^{3}$ point 1 provides that The General Meeting of the housing cooperative cannot be replaced by the Representatives Meeting, however, if the Articles of Association so provide, in case the number of members of the housing cooperative exceeds 500, the General Meeting may be split into parts. The Supervisory Board establishes the rules for assigning members to the respective parts of the General Meeting, but it is not allowed to assign members entitled to premises located within one property to different parts of the General Meeting.

From a formal and legal point of view it is the Management Board that is responsible for putting forward proposals for amendments to the Articles of Association, which are then considered by the Supervisory Board and subsequently discussed during Member Group Meetings and finally it is the Member Representatives Meeting that decides whether the suggested new solutions will be adopted or rejected.

Already now it can be predicted with exact precision that the current composition of the Supervisory Board and the Member Representatives Meeting will be interested in maintaining the current status quo, and Member Group Meetings will simply be renamed - the respective parts of the General Meeting, in order to secure the future possibility of selecting Supervisory Board 
members by a small group of residents, as opposed to according to the will of the majority of residents. Additionally, proposals for restrictions within the framework of the prohibition to be a Supervisory Board member while having debts due to unpaid rent or while running a business on the property of the cooperative will be rejected entirely ${ }^{2}$. This is how a small group of people, who perfectly know how to calculate and know that all you need is 8 trusted members of the Supervisory Board in order to have real and true control of the entire housing cooperative, functions.

Another reason for lively disputes is the request made by a group of representatives who are calling for adding the issue of separating two enclaves from the cooperative to the agenda of the Member Representatives Meeting. This is a very cleverly prepared move, inspired by a representative who at the same time is a Supervisory Board member for 3 consecutive terms, which is supposed to make it possible to separate property including attractive commercial property with free investment areas, based on the decision of 32 persons, making up 2/3 of the Member Representatives Meeting (47 people). In passing, it should be added that this is how a group of people that submitted a request during the previous sessions of the Member Representatives Meeting effectively blocked the adaptation of the Articles of Association to the applicable changes in the law, and suggested to the previous Management Board that there is no point in the adopted resolution that rejects the implementation of the necessary changes in the Articles of Association being contested by the Management Board of the cooperative on the basis of Article $42 \S 2$ and Article $42 \S 5$ of the Act Cooperative Law.

The resultant network of connections and influence would not have been possible were it not for the passivity and lack of interest on the part of the residents, who practically show no interest in the affairs of the cooperative. In reality, only those people are interested in the functioning of the cooperative who have their own personal interest in it, mainly associated with their businesses. The Member Representatives Meeting (consisting of 47 representatives) includes as many as 12 persons that simultaneously are member of the current Supervisory Board, and the rest run their own business in commercial premises obtained without a tender and on highly concessional terms, are employees of the cooperative or have signed lucrative civil law contracts with the cooperative, etc. This group of members of the cooperative will ultimately decide on the

\footnotetext{
2 The above stated predictions proved to be $100 \%$ accurate, which is another argument proving the correctness of reasoning based on the results of the conducted research - the accuracy of the observations as well as the interpretation of the sources of the analyzed processes were confirmed, because the Member Representatives Meeting that was scheduled for 15 June of the current year, which was supposed to approve the new Articles of Association of the cooperative, adjusting them to the current legal requirements (by the way, it should be added that the new legal requirements are applicable since 2007), was deliberately arranged in such a way that the deliberations were interrupted 3 times, and the fourth time there was no quorum, which means that the Meeting did not take place. Of course, the order of the agenda was changed in order to overrule the report on the activities of the Management Board as well as the financial report, as this was in the interest of the voters. The course of events was to be expected, because, as stated earlier, the Supervisory Board members includes people that do not want the Articles of Association to be adjusted, because they are both member of the Supervisory Board and of the Member Representatives Meeting, and the lack of a General Meeting only strengthens the created system, because the residents do not have a real impact on the functioning of the cooperative.
} 
shape and the provisions of the new Articles of Association, and thus on the fate of the common property of the residents of the residential complex.

The described facts seem to accurately explain why there is such a rivalry and struggle for the additional earnings amounting to $30 \%$ of the minimum wage, which currently gives the exact monthly net amount of PLN 383.50, since this is the monthly lump sum established by the Member Representatives Meeting for "working” on the Supervisory Board. Only when actually observing the deliberations of the Supervisory Board one can see that a vast majority of the members do not actually read the received materials, some of them do not even know how to use a computer or how to draw up a document, but these people do know exactly when to raise their hand and that is the most important competence of a Supervisory Board member.

Table 2 | The main determinants and factors that affect the work of the Supervisory Board of the analyzed cooperative

\section{The main factors that have the greatest impact on the functioning \\ and real attitudes of the members of the analyzed Supervisory Board}

The lack of a proper sense of responsibility for the undertaken actions, a sense of complete impunity, since all the decisions are made jointly. Another argument reinforcing the validity of the formulated notion is the fact that housing cooperatives are not included in the public finance sector, which means that the actual interest of state law enforcement authorities in activities that are detrimental to the interests of cooperatives is negligible, because cooperatives are funded by the private resources of its members, since it is their common private property.

The over the years formed system of protecting the interests and interrelations in and around the cooperative - a vast majority of the Supervisory Board members remain in office for 16 years on and off, combining their mandate with the function of representative at the Member Representatives Meeting, which is the supreme body (highest authority) of the cooperative that accepts and endorses the activity report of the Supervisory Board, grants discharge to the Management Board and is also authorized to make decisions regarding the sale of land and property of the cooperative.

The lack of substantive knowledge and relevant qualifications to ensure a proper fulfillment of the obligations imposed - especially in the field of law and economics.

A relatively very low level of remuneration disproportionate to the scope of the performed tasks and devoted time, which greatly discourages other potential people to perform such a function.

The lack of openness and transparency of the activities of the Supervisory Board and the Management Board - since the establishment of the cooperative neither the Articles of Association nor any regulations have been published on the website of the cooperative, the residents have not had access to the resolutions adopted by the authorities of the cooperative, and neither to the minutes of the meetings held.

The lack of interest of the residents in issues of common concern causes a small group of interested people to be able to easily take over power and control over the cooperative, which is supported by the Member Group election system as opposed to participation in the elections by all the residents during a General Meeting.

The deliberate and conscious failure to adjust the Articles of Association to the applicable provisions of the Act on Housing Cooperatives by the Member Representatives Meeting, which has made it possible to run for and be re-elected to the Supervisory Board for a third consecutive term. Additionally, the lack of overt, in-depth and substantive discussions during Member Group Meetings about the declared candidates resulted in the fact that even people with many thousands of debt due to unpaid rent could become Supervisory Board members, as well as people that do not pay their credit obligations or that are in litigation with the cooperative.

Source: own elaboration. 
Such knowledge cannot be acquired based on research using survey questionnaires as a tool, or interviews - the only way to obtain such knowledge is to actively participate in the activities of the housing cooperative. The presented facts on the functioning of the housing cooperative are not based on an image created as a result of getting to know the opinions of others, but are based on own experience. In light of the above circumstances an attempt was made to identify the most important factors that are most responsible for the real attitudes and organizational behaviors of the members of the analyzed Supervisory Board. It should be noted that they are all closely linked and interdependent, but the first three mentioned elements have the most impact, which is reflected in reality.

\section{| Summary}

In the studied cooperative the Supervisory Board has been dominated by the same people for many years, who together with the Management Board have created a system of interrelationships and cash flows between the cooperative and other entities, and they make sure that the created networks of connections and interests keep functioning. The functioning of the housing cooperative needs to be perceived not only in terms of the internal organizational structure, but above all, the network of connections with external entities. It is based on the decisions of the Supervisory Board that commercial premises are granted without a tender and on highly concessional terms. The Supervisory Board can also adopt resolutions to withdraw from the tender procedure and to authorize the Management Board to enter into an agreement with a contractor, who will receive a lucrative job. In reality the cooperative is entwined by an extensive network of cash flows for external entities and it is these processes that are crucial in terms of the analyzed problem. For it is a mistake to think that the Supervisory Board has no real impact on the functioning of the cooperative - in practice it has extensive possibilities to influence the decisions of the Management Board, the consequences of which entail huge cash flows into the accounts of selected beneficiaries. Many lucrative permanent contracts with external entities were signed bypassing the open and competitive tender procedures. This way, having a guaranteed majority of the votes in the Supervisory Board, it is possible to effectively eliminate potential competition, while assuring that chosen companies get the jobs. This is exactly how the system that takes control over multi-million flows of cash works. Logical arguments and reasoning are of no significance here, because in the case of an authority that makes decisions collectively the only thing that matters is the amount of votes, as opposed to substantive arguments, just like in the parliament, city councils or provincial authorities, for example. So why does this happen and does it bother anyone?

Firstly, people that have been Supervisory Board members for many years perform a dual role, being a representative at the Member Representatives Meeting as well, which is the supreme body of the cooperative and is responsible for the control over and the accounting for the actions of the Supervisory Board, which means that they control themselves. It should be added here that the information on what goes on during Supervisory Board meetings was 
previously never disclosed to the residents and propaganda newsletters informed only about the successes of the Management Board. In passing, it should be noted that it is only since 2011 that the minutes of Supervisory Board meetings are published on the website of the cooperative. However, the last decision of the majority of the Supervisory Board members was that their content should be significantly limited - i.e. only a general account of the deliberations should be given, concealing some of the discussed topics and statements of the respective Supervisory Board members. This is conscious and deliberate disinformation and censorship much like in the days of communism in Poland, which is further evidence that some Supervisory Board members want to hide important information from the residents of the housing cooperative. Reducing the content of the records of meetings and placing only convenient information in the minutes is further objective evidence for the activities of the Supervisory Board (e.g. omitting information about the amount of debt of the Supervisory Board members due to unpaid maintenance charges and the debt recovery measures undertaken against them by the Management Board, while it is the Supervisory Board that adopts resolutions regarding exclusion from membership of indebted residents). Another undeniable proof is the fact that during the last meeting the Supervisory Board has introduced changes to the rules of procedure of Member Group Meetings, which will soon be held, making it impossible for Supervisory Board members to contribute to the meetings of other enclaves, which demonstrates how badly some of the Supervisory Board members want the residents to know as little as possible about what is happening in the cooperative. Secondly, the residents are not interested in the functioning of the cooperative - the last few Member Group Meetings were attended by just over $2 \%$ of the eligible people, which is like an expression of acceptance and tolerance for the actions of the Supervisory Board and the Member Representatives Meeting. This is the real cause of many pathologies and negative phenomena that occur in housing cooperatives. If the tenants are not interested in the functioning of the cooperative and while having the opportunity to take part in the deliberations of the Supervisory Board they do not wish to do so, the Supervisory Board members, in fact, are not subject to any control and feel that they can get away with anything.

It should be noted here that the legislature has created for the members of cooperatives the opportunity for an extensive and real participation in the processes of corporate governance, which is not subject to any discussion. It should be remembered that pursuant to Article $8^{1}$ of the Act on Housing Cooperatives each member of the cooperative has not only the right to receive copies of resolutions and minutes of meetings of the cooperative bodies, as well as lustration protocols, but also copies of the annual financial reports as well as invoices and contracts signed by the cooperative with third parties - unfortunately, hardly anyone is aware of the fact that they have the right of access to such documents. The rest depends only on the people themselves, who are mostly not interested in building a civil society, even on the scale of a residential complex. That is why it is necessary and worthwhile to popularize the knowledge in this field and to make people become more and more aware of the fact that the way in which their common property is managed greatly depends on their actual involvement. 
The important role and significance of housing cooperatives as an important element of the socio-economic system is beyond doubt. It should be mentioned here that the United Nations General Assembly has declared 2012 as the International Year of Cooperatives, which confirms the rank and importance of the cooperative management system. The UN resolution states that the cooperative business model is becoming a major factor of economic and social development and promotes the fullest possible participation of all people in this development, both in developed and developing countries - cooperatives effectively contribute to the eradication of poverty, the generation of employment and the enhancement of social integration.

Figure 1 | Logo of the International Year of Cooperatives 2012

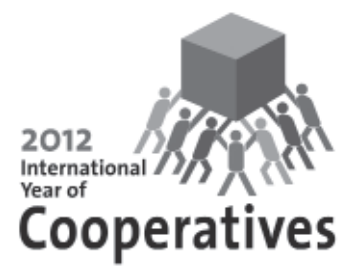

Source: http://krs.org.pl (29.03.2012).

The slogan of the International Year of Cooperatives 2012: "Cooperative Enterprises Build A Better World" highlights the enormous contribution of cooperatives to the socio-economic development of mankind at all levels, from the local level all the way through to the international community. It also emphasizes that economic efficiency cannot be separated from social responsibility.

Figure 2 | Slogan of the International Year of Cooperatives 2012: "Cooperative Enterprises Build A Better World"

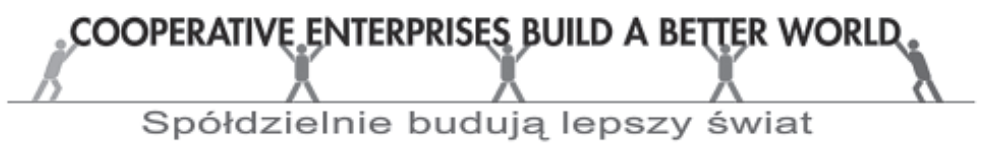

Source: http://krs.org.pl (29.03.2012).

When comparing these noble slogans to the organizational reality of the analyzed housing cooperative and the mechanisms of corporate governance it is clear that the Polish legislation setting out the framework for the functioning of cooperatives provides a basis for the implementation of the idea of a civil and solidary state - building a local community that can, and most of all 
wants to, look after its own interests. The applicable law respects the self-rule, independence and autonomy of housing cooperatives, and in this respect there can be no objections. The most serious problem is that residents do not want to actively participate in the life of their cooperative and they prefer to be passive observers, often without knowing their basic rights.

The openness and transparency of activities and open communication with residents is a very important element that has a crucial impact on the credibility of the Supervisory Board, and most of all, it is a factor that helps build relationships based on mutual trust. The aim should be to ensure that cooperative members have access to reliable and accurate information on current events, which may cause them to start showing more interest in issues of common concern.

$R$ e $f$ e $r$ e $n$ c e s

Aluchna, M. (2007) Mechanizmy corporate governance w spółkach giełdowych. Warszawa: Oficyna Wydawnicza Szkoły Głównej Handlowej.

Dobija, D. and Koładkiewicz, I. (ed.) (2011). Ład korporacyjny. Warszawa: Wolters Kluwer Polska.

Jeżak, J. (2010). Ład korporacyjny. Doświadczenia światowe oraz kierunki rozwoju. Warszawa: C.H. Beck.

Jerzemowska, M. (2002). Nadzór korporacyjny. Warszawa: PWE.

Konecki, K. (2010). Studia z metodologii badań jakościowych. Teoria ugruntowana. Warszawa: Wydawnictwo Naukowe PWN.

Kostera, M. (2008). Antropologia organizacji. Warszawa: Wydawnictwo Naukowe PWN.

Koźmiński, A.K. (2005). Zarzq̨dzanie w warunkach niepewności. Warszawa: Wydawnictwo Naukowe PWN.

Matejun, M. (2011). Metoda studium przypadki w pracach badawczych młodych naukowców z zakresu nauk o zarządzaniu, Zeszyty Naukowe Uniwersytetu Szczecińskiego, nr 666 Problemy Zarzq̨dzania, Finansów i Marketingu, 19.
Peszko, A. (2006). Rada nadzorcza w procesie zarzq̨dzania przedsiębiorstwem. Warszawa: Difin.

Rudolf, S.(ed.) (2008). Rola nadzoru korporacyjnego w kreowaniu wartości przedsiębiorstwa. Łodź: Wydawnictwo Uniwersytetu Łódzkiego.

Silverman, D. (2010). Prowadzenie badań jakościowych. Warszawa: Wydawnictwo Naukowe PWN.

Walczak, W. (2011a). Funkcjonowanie rad nadzorczych w spółdzielniach mieszkaniowych. Przegląd Corporate Governance, 3(27).

Walczak, W. (2011b). Współpraca rady nadzorczej i zarządu w spółdzielni mieszkaniowej-studium przypadku. Przegląd Corporate Governance, 4(28).

L e g a I A c t s

The Act of 16 September 1982 Cooperative Law (Journal of Laws of 1982 No. 30, item 210, as amended).

The Act of 15 December 2000 on Housing Cooperatives (Journal of Laws of 2001, No. 4, item 27, as amended).

http://www.krs.org.pl/aktualnosci/miedzynarodowy-rokspoldzielczosci-2012-proklamowany,281,.html 